$\sqrt{B}$

J. bio-sci. 15: 69-75, 2007

ISSN 1023-8654

http://www.banglajol.info/index.php/JBS/index

\title{
INFLUENCE OF IRRIGATION, FERTILIZER AND VARIETY ON GRAIN GROWTH OF BARLEY (HORDEUM VULGARE L.)
}

\author{
M S I Mollah and N K Paul ${ }^{*}$ \\ *Institute of Biological Sciences, Rajshahi University, Rajshahi, Bangladesh \\ 2Department of Botany, Rajshahi University, Rajshahi, Bangladesh
}

\begin{abstract}
An experiment was conducted in the experimental field of Rajshahi University Campus (AEZ-11) to study the influence of soil moisture and NPK fertilizers on grain growth of four varieties of barley (Hordeum velgare L.). Spikelet number (SN), spike dry weight (SDW), grain number (GN), grain dry weight (GDW), spike relative growth rate (spike RGR) and grain relative growth rate (grain RGR) were observed highest in the highest level of irrigation $(40 \mathrm{~mm})$. The highest amount of fertilizer (120N 75P $45 \mathrm{~K}$ ) produced the highest SN, SDW, GN, GDW, spike RGR and grain RGR. BHL-3 produced the highest SN, BARI Barley -2 produced the highest spike RGR, BARI Barley-1 produced the highest grain RGR and BL-1 produced the highest SDW, GN, and GDW.
\end{abstract}

Key words: Irrigation, soil moisture, fertilizers, barley, grain growth.

\section{Introduction}

As an important cereal crop, barley is cultivated successfully in a wider range of climate of all over the world. In Bangladesh, it is grown in some areas, mainly in the northern parts, as a rabi crop. It ranks third after rice and wheat as supplementary food and fodder crops of Bangladesh (FAO 2002). Barley is used for direct human consumption, animal feed, poultry feed, malt extract for manufacture of beverages, human food in the form of parched grain, pearled grain for soap, flour for bread, and partly ground grain as porridge. People from Bangladesh and India prefer barley as flour with molasses, milk or ripe mango as well as chapati made by mixing barley and wheat flour. It is a staple food in the mountainous areas of Afganistan, India and Nepal. The area and production of barley for the fiscal year 1991-92 were 40000 acres and 10000 tons, respectively whereas it was 3000 acres and 1000 tons in 2004-2005, respectively (BBS 2005). Barley though a minor crop, can play an important role in enhancing the food security of the country. But the productivity of this crop is very low compared to that of many other countries. Lack of irrigation facilities, increased cost of irrigation and fertilizers, lack of stress tolerant high yielding varieties are responsible for this. Moreover, farmers of this country use different fertilizers indiscriminately without adequate information concerning actual soil requirements and these results in over or under application. A clear understanding on use of different doses of NPK fertilizers and their utilization efficiency are pre-requisite to avoid indiscriminate use of fertilizers.

Very little work has been done in Bangladesh to develop a package of improved management practices required to achieve higher yield of this cereal crop. Thus, the present experiment was undertaken to find out the effect of soil moisture and NPK fertilizers on grain growth of four varieties of barley.

\footnotetext{
* To whom all correspondence should be addressed.
} 


\section{Materials and Methods}

The experiment was conducted in the experimental field of Rajshahi University campus (AEZ-11) during from November 2004 to March 2005 with four barley varieties, BARI Barley-1, BARI Barley-2, BHL-3 and BL-1. The soil of the field was silty loam, having pH 7.5 as well as $35 \%$ of field capacity. The experiment was arranged in spliesplit plot design with three replications. Each replicated field was divided into three main plots for irrigation treatment. Each main plot divided into four sub-plots for varieties of barley. Three levels of irrigation treatments $\left(0,20\right.$, and $40 \mathrm{~mm}$ as $l_{0}, l_{1}$ and $l_{2}$ respectively) were adopted at every 30 day's interval for three times during the growing period. Four levels of NPK used ( $\mathrm{kg} / \mathrm{ha}$ ) for $\mathrm{N}$ as urea were $0,40,80$ and 120; for $P$ as TSP were $0,25,50$ and 75 and lastly for $K$ as MP were $0,15,30$ and 45 . These basal doses of fertilizers were applied as $F_{0}, F_{1}, F_{2}$ and $F_{3}$ at each split plot before sowing. Each split plot size was $4 \mathrm{~m}$ ? 1.8 $\mathrm{m}$, i.e., $7.2 \mathrm{~m}$ h having a plot to plot distance $1 \mathrm{~m}$ to the North-South, $2 \mathrm{~m}$ to East - West, replication to replication distance $2 \mathrm{~m}$, row to row $20 \mathrm{~cm}$, and plant to plant $5 \mathrm{~cm}$. Necessary intercultural operations were adopted, but no fungicides or insecticides were used. At equal intervals of seven days after anthesis (DAA), five grain harvests were done for grain growth analysis. For this, main spike plant ${ }^{-1}$ treatment $^{-1}$ variety $^{-1}$ replication-1 was selected, tagged with identifying marks to collect them at 7, 14, 21, 28 and 35 DAA. At each harvest, the spikes were packed separately in labelled paper bags and were oven dried for 72 hours at $85^{\circ} \mathrm{C}$. Various components of grain growth analysis were spikelet number (SN), spike dry weight (SDW), grain number (GN) and grain dry weight (GDW). Grain growth parameters were spike relative growth rate (spike $R G R$ ) and grain relative growth rate (grain RGR) determined from between two successive harvests of spike and grain growth stages by using the following formulae according to the classical technique of growth analysis (Radford 1967).

$$
\stackrel{?}{?} \text { RGR } ? \frac{\log _{\mathrm{e}} \mathrm{W}_{2} ? \log _{\mathrm{e}} \mathrm{W}_{1}}{\mathrm{t}_{2} ? \mathrm{t}_{1}} \stackrel{?}{?}
$$

where, $W_{2}$ and $W_{1}$ are the spike or grain dry weights per spike (main tiller) at the later ( $($ ) $)$ and the former ( $\downarrow$ ) grain growth harvest, respectively. Statistical analysis was done according to Gomez and Gomez (1984).

\section{Results and Discussion}

Irrigation increased the number of spikelets spike-1, thus the $b$ treatment produced the highest spikelet number (Table 1). The lowest spikelet number was produced by the non-irrigated plants. This result is corroborated with Okuyama and Igarashi (1990), Rahman et al.(2001), Haider (2002) and Rahman (2004) in wheat. Irrigated plants had higher SDW than the rainfed plants. Rahman and Paul (1998) noticed similar findings in wheat. The highest GN spike-1 was in the irrigated plants ( $I_{2}$ treatment). Similar results were reported by Labuschagne and Van-Deventer (1992) and Rahman (2004) in wheat. The highest GDW was in the $I_{2}$ treatment and the lowest was in the control. Similar results were also stated by Machodo and Paulsen (2001), Haider (2002) and Rahman (2004) in wheat. Rainfed condition resulted in the lowest RGR of spike. $I_{2}$ treatment had the highest RGR of spike at the first harvest interval. Higher grain RGR was in the irrigated plants than in the rainfed plants. The highest grain RGR was in the $k_{2}$ treatment. This result is in agreement with Haider (2002) in wheat. 
Table 1. Influence of irrigation on mean values of spikelet number,spike dry weight (g), grain number, grain dry weight (g), spike RGR ( $g^{-1}$ day $^{-1}$ ) and grain RGR ( $g^{-1}$ day-1) $^{-1}$ at different days after anthesis.

\begin{tabular}{|c|c|c|c|c|c|c|c|c|c|c|}
\hline \multicolumn{6}{|c|}{ Days After Anthesis ( DAA ) } & \multicolumn{5}{|c|}{ Days After Anthesis ( DAA ) } \\
\hline & 07 & 14 & 21 & 28 & 35 & 07 & 14 & 21 & 28 & 35 \\
\hline \multicolumn{6}{|c|}{ Spikelet number } & \multicolumn{5}{|c|}{ Spike dry weight ( $\mathrm{g}$ ) } \\
\hline \multirow[t]{2}{*}{$\mathrm{I}_{0}$} & 45.438 & 45.531 & 45.531 & 45.531 & 45.531 & 0.593 & 0.888 & 1.071 & 1.288 & 1.514 \\
\hline & 48.156 & 48.156 & 48.156 & 48.156 & 48.156 & 0.649 & 1.072 & 1.357 & 1.775 & 2.195 \\
\hline $\mathrm{I}_{2}$ & 48.156 & 48.156 & 50.219 & 50.219 & 50.219 & 0.649 & 1.072 & 1.455 & 2.268 & 2.712 \\
\hline $\begin{array}{c}\text { SD } \\
(5 \%)\end{array}$ & 0.124 & 0.188 & 0.459 & 0.124 & 0.124 & 0.001 & 0.006 & 0.052 & 0.008 & 0.061 \\
\hline \multicolumn{6}{|c|}{ Grain number } & \multicolumn{5}{|c|}{ Grain dry weight $(\mathrm{g})$} \\
\hline $\mathrm{I}_{0}$ & 29.719 & 28.344 & 25.563 & 24.063 & 24.063 & 0.335 & 0.459 & 0.549 & 0.637 & 0.799 \\
\hline $\mathrm{I}_{1}$ & 35.063 & 33.188 & 30.406 & 28.750 & 28.750 & 0.422 & 0.526 & 0.616 & 0.764 & 0.986 \\
\hline$I_{2}$ & 35.063 & 32.813 & 34.406 & 32.938 & 32.938 & 0.422 & 0.526 & 0.800 & 0.984 & 1.199 \\
\hline \multirow[t]{2}{*}{$\begin{array}{c}\mathrm{SD} \\
(5 \%)\end{array}$} & 0.617 & 0.524 & 0.585 & 0.810 & 0.810 & 0.003 & 0.002 & 0.016 & 0.018 & 0.004 \\
\hline & $07-14$ & $14-21$ & $21-28$ & 28-35 & & $07-14$ & $14-21$ & $21-28$ & $28-35$ & \\
\hline \multicolumn{6}{|c|}{ Spike RGR ( gg-1 $^{-1}$ day ${ }^{-1}$ ) } & \multicolumn{5}{|c|}{ Grain RGR ( $g g^{-1}$ day $\left.^{-1}\right)$} \\
\hline$I_{0}$ & 0.056 & 0.029 & 0.028 & 0.025 & & 0.044 & 0.026 & 0.020 & 0.030 & \\
\hline$I_{1}$ & 0.068 & 0.035 & 0.043 & 0.033 & & 0.031 & 0.025 & 0.027 & 0.039 & \\
\hline $\mathrm{I}_{2}$ & 0.068 & 0.045 & 0.068 & 0.028 & & 0.031 & 0.064 & 0.025 & 0.030 & \\
\hline $\begin{array}{c}\mathrm{SD} \\
(5 \%)\end{array}$ & 0.0031 & 0.0051 & 0.0031 & 0.0031 & & 0.0003 & 0.0004 & 0.0021 & 0.0026 & \\
\hline
\end{tabular}

Fertilized plants produced higher number of spikelets spike-1 than that of non-fertilized plants (Table 2). $F_{3}$ treatment produced the highest SN as SN spike-1 increased with the increase of NPK fertilization. Similar trend of the influence of fertilizer ( $\mathrm{N}$ ) was noticed in barley by Malesevic et al. (1981), Bianchi and Ciriciofolo (1982), Basso (1983), Shim et al., (1998) and Alam (2003) and in wheat by Singh et al., (1992), Patel et al. (1995), Tarique (2003), Rahman (2004), and Khaleque (2005). Higher SDW was produced by the fertilized plants than that of the control. This result is also corroborated with Rahman (2004) and Khaleque (2005) in wheat. $F_{3}$ fertilized plants produced the highest GN spike-1 and Ellen (1990), Rahman et al.(1999), Tarique (2003), Rahman (2004) and Khaleque (2005) noticed similar findings in wheat. Higher GDW was in the fertilized plants than in the control. Increased GDW was produced by increasing the fertilizer level. $F_{3}$ treatment had the highest GDW. Haque (2000), Rahman (2004) and Khaleque (2005) reported similar findings in wheat. The highest spike RGR was in the $F_{3}$ treatment. The lowest grain RGR was in the nonfertilized plants at all the days after anthesis. Fertilized plants had higher grain RGR than the control. The highest grain RGR was in the $F_{3}$ treatment. Rahman (2004) and Khaleque (2005) noticed similar findings in wheat. 
Table 2. Effect of fertilizer on mean values of spikelet number, spike dry weight (g), grain number, grain dry weight (g), spike RGR ( $g^{-1}$ day-1 $^{-1}$ ) and grain RGR ( $g^{-1}$ day $\left.^{-1}\right)$ at different days after anthesis.

\begin{tabular}{|c|c|c|c|c|c|c|c|c|c|c|}
\hline \multicolumn{6}{|c|}{ Days After Anthesis (DAA) } & \multicolumn{5}{|c|}{ Days After Anthesis (DAA) } \\
\hline & 07 & 07 & 14 & 21 & 28 & 07 & 14 & 21 & 28 & 35 \\
\hline \multicolumn{6}{|c|}{ Spikelet number } & \multicolumn{5}{|c|}{ Spike dry weight ( $\mathrm{g}$ ) } \\
\hline $\mathrm{F}_{0}$ & 39.750 & 39.750 & 40.125 & 40.125 & 40.125 & 0.325 & 0.455 & 0.651 & 1.038 & 1.461 \\
\hline $\mathrm{F}_{1}$ & 44.625 & 44.625 & 45.375 & 45.375 & 45.375 & 0.575 & 0.971 & 1.180 & 1.638 & 1.906 \\
\hline $\mathrm{F}_{2}$ & 49.875 & 49.875 & 50.750 & 50.750 & 50.750 & 0.760 & 1.156 & 1.397 & 2.003 & 2.349 \\
\hline $\mathrm{F}_{3}$ & 54.750 & 54.750 & 55.500 & 55.500 & 55.500 & 0.862 & 1.465 & 1.954 & 2.445 & 2.839 \\
\hline $\begin{array}{l}\text { LSD } \\
(5 \%)\end{array}$ & 0.801 & 0.796 & 0.902 & 0.962 & 0.962 & 0.011 & 0.034 & 0.062 & 0.075 & 0.130 \\
\hline \multicolumn{6}{|c|}{ Grain number } & \multicolumn{5}{|c|}{ Grain dry weight ( g) } \\
\hline Fo & 22.917 & 22.083 & 20.500 & 19.083 & 19.083 & 0.181 & 0.241 & 0.355 & 0.399 & 0.534 \\
\hline F1 & 27.750 & 26.125 & 25.042 & 23.833 & 23.833 & 0.370 & 0.412 & 0.543 & 0.594 & 0.742 \\
\hline $\mathrm{F} 2$ & 39.375 & 37.000 & 36.042 & 34.083 & 34.083 & 0.495 & 0.632 & 0.776 & 0.995 & 1.230 \\
\hline F3 & 43.083 & 40.750 & 39.083 & 37.500 & 37.500 & 0.526 & 0.732 & 0.947 & 1.191 & 1.479 \\
\hline \multirow[t]{2}{*}{$\begin{array}{l}\text { LSD } \\
(5 \%)\end{array}$} & 0.501 & 0.991 & 1.183 & 1.260 & 1.260 & 0.009 & 0.004 & 0.016 & 0.038 & 0.047 \\
\hline & $07-14$ & $14-21$ & $21-28$ & $28-35$ & & 07-14 & $14-21$ & $21-28$ & $28-35$ & \\
\hline \multicolumn{6}{|c|}{ Spike RGR ( gg $^{-1}$ day $^{-1}$ ) } & \multicolumn{5}{|c|}{ Grain RGR ( $g^{-1}$ day $^{-1}$ ) } \\
\hline Fo & 0.048 & 0.051 & 0.064 & 0.047 & & 0.041 & 0.052 & 0.017 & 0.040 & \\
\hline F1 & 0.074 & 0.027 & 0.045 & 0.021 & & 0.016 & 0.037 & 0.014 & 0.031 & \\
\hline F2 & 0.060 & 0.026 & 0.048 & 0.024 & & 0.035 & 0.029 & 0.034 & 0.031 & \\
\hline F3 & 0.075 & 0.040 & 0.030 & 0.021 & & 0.048 & 0.035 & 0.032 & 0.032 & \\
\hline $\begin{array}{l}\text { LSD } \\
(5 \%)\end{array}$ & 0.006 & 0.006 & 0.006 & 0.008 & & 0.0034 & 0.0007 & 0.0038 & 0.0052 & \\
\hline
\end{tabular}


Table 3. Mean values of spikelet number,spike dry weight (g), grain number, grain dry weight (g), spike RGR ( gg $^{-1}$ day $\left.^{-1}\right)$ and grain RGR ( gg-1 $^{-1}$ day $^{-1}$ ) at different days after anthesis as affected by variety.

\begin{tabular}{|c|c|c|c|c|c|c|c|c|c|c|}
\hline \multicolumn{6}{|c|}{ Days After Anthes is (DAA) } & \multicolumn{5}{|c|}{ Days After Anthesis (DAA) } \\
\hline & 07 & 07 & 14 & 21 & 28 & 07 & 07 & 14 & 21 & 28 \\
\hline \multicolumn{6}{|c|}{ Spikelet number } & \multicolumn{5}{|c|}{ Spike dry weight ( $g$ ) } \\
\hline $\begin{array}{l}\text { BARI } \\
\text { Barley-1 }\end{array}$ & 45.875 & 45.875 & 46.750 & 46.750 & 46.750 & 0.612 & 0.992 & 1.281 & 1.761 & 2.109 \\
\hline $\begin{array}{l}\text { BARI } \\
\text { Barley-2 }\end{array}$ & 47.250 & 47.250 & 47.625 & 47.625 & 47.625 & 0.633 & 1.038 & 1.272 & 1.769 & 2.231 \\
\hline BHL-3 & 50.875 & 50.875 & 51.250 & 51.250 & 51.250 & 0.631 & 0.988 & 1.300 & 1.775 & 2.070 \\
\hline BL-1 & 45.000 & 45.000 & 46.125 & 46.125 & 46.125 & 0.646 & 1.030 & 1.328 & 1.818 & 2.145 \\
\hline $\operatorname{LSD}(5 \%)$ & 0.516 & 0.535 & 0.765 & 0.693 & 0.693 & 0.018 & 0.041 & 0.007 & 0.091 & 0.076 \\
\hline \multicolumn{6}{|c|}{ Grain number } & \multicolumn{5}{|c|}{ Grain dry weight ( $g$ ) } \\
\hline BARI & & & & & & & & & & \\
\hline Barley -1 & 31.500 & 29.542 & 28.125 & 26.042 & 26.042 & 0.373 & 0.494 & 0.645 & 0.751 & 0.865 \\
\hline BARI & & & & & & & & & & \\
\hline Barley -2 & 33.667 & 31.333 & 29.958 & 28.625 & 28.625 & 0.398 & 0.504 & 0.654 & 0.777 & 1.010 \\
\hline BHL-3 & 32.875 & 31.917 & 30.417 & 29.167 & 29.167 & 0.393 & 0.506 & 0.658 & 0.815 & 1.037 \\
\hline BL-1 & 35.083 & 33.167 & 32.167 & 30.667 & 30.667 & 0.408 & 0.513 & 0.664 & 0.837 & 1.072 \\
\hline \multirow[t]{2}{*}{$\operatorname{LSD}(5 \%)$} & 0.456 & 1.159 & 0.762 & 0.468 & 0.468 & 0.009 & 0.008 & 0.024 & 0.045 & 0.028 \\
\hline & $07-14$ & $14-21$ & $21-28$ & $28-35$ & & 07-14 & $14-21$ & $21-28$ & $28-35$ & \\
\hline \multicolumn{6}{|c|}{ Spike RGR ( gg $^{-1}$ day $\left.^{-1}\right)$} & \multicolumn{5}{|c|}{ Grain RGR ( $g g^{-1}$ day $\left.^{-1}\right)$} \\
\hline BARI & & & & & & & & & & \\
\hline Barley-1 & 0.064 & 0.038 & 0.047 & 0.029 & & 0.041 & 0.039 & 0.020 & 0.020 & \\
\hline $\begin{array}{l}\text { BARI } \\
\text { Barley -2 }\end{array}$ & 0.066 & 0.030 & 0.049 & 0.036 & & 0.033 & 0.038 & 0.022 & 0.038 & \\
\hline BHL-3 & 0.062 & 0.040 & 0.044 & 0.022 & & 0.035 & 0.038 & 0.026 & 0.036 & \\
\hline BL-1 & 0.064 & 0.037 & 0.047 & 0.026 & & 0.032 & 0.038 & 0.028 & 0.039 & \\
\hline LSD (5\%) & 0.0056 & 0.0060 & 0.0071 & 0.0050 & & 0.0024 & 0.0047 & 0.0049 & 0.0047 & \\
\hline
\end{tabular}

Although the varietal differences were significant for all the characters studied, but the ranking of the varieties was different for different characters (Table 3). BHL-3 had the highest SN spike-1, BL-1 produced the highest SDW, GN and GDW. The highest spike RGR was produced by BARI Barley-2. BARI Barley-1 had the highest grain RGR.

In this study, grain growth of the four barley varieties was observed highest in the highest level of irrigation and fertilizer than the control. So, proper grain growth is very much dependent on the availability of adequate amount of soil moisture and adequate quantity of fertilizer. 


\section{References}

Alam M Z (2003) Influence of planting dates and nitrogen levels on growth, grain yield and nitrogen utilization of barley (Hordeum vulgare L.). Ph D Thesis. Crop Phy siology Laboratory, Department of Botany, Rajshahi University, Rajshahi. pp. 61-292.

BARI (Bangladesh Agricultural Research Institute) (2003-2004) Barley Improvement. Annual Research Report. Plant Breeding Division. Joydebpur, Gazipur. p.1.

Basso F (1983) Barley (Hordeum vulgare L.) varieties and nitrogen fertilization in the hilly area of Basilicata. 1: Grain yield. Rivista di Agronomia 17(1): 55-62.

BBS (2005) Statistical Yearbook of Bangladesh, Bangladesh Bureau of Statistics, Planning Division, Ministry of Planning, Government of People's Republic of Bangladesh. Agriculture: Crops, Livestock, Forestry and Fishery 25:141.

Bianchi A A and Ciriciofolo E (1982) Nitrogen fertilizer applications to barley Hordeum vulgare L.) Note 2. Effect of increasing rates. Rivista di Agronomia 16(4): 344-352.

Ellen J (1990) Effects of nitrogen and plant density on growth, yield and chemical composition of two winter wheat cultivars. J. Agron. \& Crop Sci. 164:174-183.

FAO (2002) FAOSTAT: Statistics database (Online.) (Subset Production within Agriculture database) Available at http: 11 apps. fao.org

Gomez K A and Gomez A A (1984) Statistical procedure for agricultural research. John Wiley and Sons. New York.

Haider S A (2002) Effect of water stress on the physiology and grain yield of four bread wheat (Triticum aestivum L.) cultivars. Ph D Thesis. Crop physiology Laboratory, Department of Botany, Rajshahi University. Rajshahi. pp. 71-342.

Haque M M (2000) Physiological analysis of yield of wheat (Tritium aestivum L.) in relation to sowing date. Ph D Thesis. I B Sc, Rajshahi University, Rajshahi. pp. 43-317.

Ikegami S F, Tsuchihashi K, Nakamura and S Innami (1991) Effects of barley on development of diabetes in rats. J. Jap.Soc. Nut. and Food Sci. 44(6): 447-454.

Khaleque M A (2005) Study on growth and yield of modern wheat varieties in different agronomic management practices. Ph D Thesis. Institute of Biological Sciences, Rajshahi University. Rajshahi. pp. 53-243.

Labuschange M T and Van-Deventer C S (1992) The effect of moisture stress on the yield and yield components of several wheat cultivars and their $F_{1}$ hybrids. J. Agron. \& Crop Sci. 168(3): 153-158.

Machado S and Paulsen G M (2001) Combined effects of drought and high temperature on water relations of wheat and sorghum. Plant and Soil 233(2): 179-187.

Malesevic M, Drezgic P, Starcevic $L$ and Spasojevic B (1981) Effect of increasing doses of nitrogen on yield and quality of malting barley. Zemljiste i Biljka 30(2): 183-190.

Okuyama L A and lgarashi S (1990) Grain yield and yield components of wheat as a function of water stress at tillering stage. Informa-da-Pesquisa-Instituto-Agronomic-Da-Parana 94: 49-52.

Patel N M, Sadaria S G, Kaneria B B and Khanpara V D (1995) Effect of nitrogen, potassium and zinc on growth and yield of wheat (Triticum aestivum). Indian J. Agron. 40(2): 290-292. 
Radford P J (1967) Growth analysis formulae-their use and abuse. Crop Sci. 7: 171-175

Rahman M A (2004) Effect of irrigation on nitrogen uptake, yield and yield attributes of wheat varieties. Ph D Thesis. Crop Physiology Laboratory, Department of Botany, Rajshahi University. pp. 45-257.

Rahman M A, Karim A J M S, Solaiman A R M, Haque M M and Saifuddin K M (1999) Water use, yield and yield components of wheat under irrigation and nitrogen application in terrace soil of Bangladesh. Ann. Bangladesh Agric. 9(2): 191-204.

Rahman M S and Paul N K (1998) Effect of soil moisture regimes on physiological characters and yield of wheat cultivars. J.bio-sci. 6: 5-10.

Rahman M S, Sarker A M, Islam M S and Paul N K (2001) Effect of soil moisture on grain yield of wheat (Triticum aestivum L.) cultivars. Environment \& Ecol. 19(2): 304-308.

Shim J W, Lee H S and Choi K J (1988) Effect of soil acidity and nitrogen fertilization on the growth and yield of barley cultivars. Korean J. Crop Sci. 33(1): 12-22.

Singh R V, Dubey V K and Vyas M D (1992) Effect of seed rate, nitrogen level and method of fertilizer placement on wheat (Triticum aestivum) under the sown condition. Indian J. Agron. 37(1): 43-46.

Tarique M H (2003) Growth and yield of wheat (Triticum aestivum L.) in relation to NPK fertilizers and competition. Ph D Thesis. Crop Physiology Laboratory, Department of Botany, Rajshahi University, Rajshahi. pp. 51-145, 149-258. 